\title{
The works of E.M. Uhlenbeck (1913-2003) An annotated bibliography ${ }^{1}$
}

Eugenius Marius Uhlenbeck - Bob as he was known to his friends - was a multifacited (or many-sided) and multi-talented person. He was an accomplished scholar in the fields of Javanese language and literature and in general linguistics holding the chairs in these disciplines at Leiden University from 1950-1983 and 1958-1979 respectively. In the Netherlands and abroad he was widely acclaimed as an elder 'statesman' ${ }^{2}$ His publications reflect his rare combination of talents. I will limit myself here to brief comments about his publications on linguistics, both general and Javanese linguistics. Bob was convinced that linguistic descriptions should be theory-driven and conversely, that linguistic theory-building should be based on exhaustive analyses of natural language data derived from a wide range of different languages and different language families. Hence he systematically backed his numerous publications on Old and Modern Javanese with theoretical articles, especially on morphology, syntax, semantics and the relation between word and morpheme as well as that between word and sentence. Bob belonged to the theoretical school of European structuralist; later he would qualify his position as that of a 'functional structuralist' (Uhlenbeck 1987b). He was keenly aware of the continuity between Neo-Bloomfieldian (aka American structuralist) and generativist conceptions of language (Uhlenbeck 1979a). As one of the editors of Lingua (1950-1983) he was personally involved in the genesis and development of generative grammar, of which he became one of its first and certainly one of its most tenacious critics (Uhlenbeck 1973a). He emphasized the centrality of the word as the fundamental unit of language and denounced the overemphasis on formal aspects of grammar to the neglect of semantics, in Neo-Bloomfieldian and generativist theories of language. The centrality of the word clearly emerges from Bob's theory of morphology, according to which 'morphemes are always dependent on and subordinate to the word category

1 The following bibliography is a revised and annotated update of an earlier version published in 1996 in the Bio-Bibliographical Series of the Centre international de Dialectologie générale of the Katholieke Universiteit Leuven (Janse and Swiggers 1996:19-33). It is completely crossreferenced, annotated and provided with an index for ease of reference. I would like to thank Mrs Mariëtte Uhlenbeck-Winkel for her assistance in the compilation of the bibliography.

2 Grace 1998:78. For bio-bibliographical essays on E.M. Uhlenbeck, see Janse and Swiggers 1996; Adelaar 2003; Janse 2004; Portielje 2004; Muysken 2005. For shorter notes, see Janse 1998b; Kooij and Steinhauer 2004. 
in which they appear' (Uhlenbeck 1992b:8). This insight was applied with scientific rigour in his studies on Javanese morphology, most of which were conveniently collected in 1978 (Uhlenbeck 1978a). The relation of the word to the sentence, the other fundamental unit in Bob's conception of language, is the topic of a number of foundational publications (for example, Uhlenbeck 1983d). The sentence provides the framework within which words act and interact. Combining words into larger units brings about interaction between and the integration of the meanings of the individual words, thereby restricting the inherent dynamicity and flexibility of word meanings. Even in his initial descriptions of the syntactic structures in Javanese he took into account intonational features (Uhlenbeck 1965b). At first Bob used them in the analysis of word groups only, but he soon realized that intonational features also played an important part in the analysis of the sentence as a whole. This led him to distinguish between word group on the one hand, and sentence segment on the other (Uhlenbeck 1975c). The phenomenon of sentence segmentation, or intonational phrasing as it is commonly referred to, was explicitly connected with the Prague School concept of Functional Sentence Perspective; he applied it to Old and Modern Javanese alike (Uhlenbeck 1994c). A final example of how well-informed Bob was in the theoretical field, was the introduction of clitics, probably one of the most hotly debated grammatical categories, into his description of the grammar of Old Javanese (Uhlenbeck 1986b).

The following bibliography claims to be definitive (although two items are as yet unpublished). It is organized chronologically and provided with an elementary index for ease of reference. Dutch titles are translated and more enigmatic titles (often short comments) have been annotated whenever this seemed useful. New editions, reprints, revised versions and translations are cross-referenced. 
1941a Beknopte Javaansche grammatica [Concise Javanese grammar]. Batavia: Volkslectuur, 107 pp. [Balé Poestaka, Grammatica Serie 1429.]

$1941 \mathrm{~b}$ 'Interessante vertalingen' [Interesting translations], Tijdschrift voor Indische Taal-, Land-en Volkenkunde (TBG) 81:295-306.

1941c 'De plaats van de moedertaal, het Nederlandsch en het Maleis' [The place of the mother tongue, Dutch and Malay], Indisch Weekblad (26 September 1941):10.

1948 'De betekenis van de phonologie' [The importance of phonology], Tijdschrift voor Indische Taal-, Land- en Volkenkunde (TBG) 82:312-29.

1949 De structuur van het Javaanse morpheem [The structure of the Javanese morpheme]. Bandung: Nix, 240 pp. [Koninklijk Bataviaasch Genootschap van Kunsten en Wetenschappen, Verhandelingen 78.] [PhD thesis; see 1950b, 1966c.]

1950a De tegenstelling krama: ngoko; Haar positie in het Javaanse taalsysteem [The opposition krama : ngoko; Its position in the Javanese language system]. Groningen: Wolters, 28 pp. [Revised English version in 1978a:278-99.]

$1950 \mathrm{~b}$ 'The structure of the Javanese morpheme', Lingua 2:239-70. [Reprinted as 1966c; revised version in 1978a:10-39.]

1950c [Review of:] C.F.P.Stutterheim, Inleiding tot de taalphilosophie (Antwerpen, 1949), Tijdschrift voor Nederlandse Taal- en Letterkunde 68:234-40.

1951

1951a [Review of:] J.H.M.C. Boelaars, The linguistic position of South-Western New Guinea (Leiden, 1950), Bijdragen tot de Taal-, Land-en Volkenkunde 107:90-2.

1951b [Review of:] Bingkisan Budi. Een bundel opstellen aan Dr. Philippus Samuel van Ronkel ('s-Gravenhage: Sijthoff), Bijdragen tot de Taal-, Land- en Volkenkunde 107:92-4.

1951c [Review of:] Bibliographie linguistique 1939-1947 (Utrecht, 1949), Bijdragen tot de Taal-, Land-en Volkenkunde 107:94.

1952a [Review of:] D.W.N. de Boer, Beknopte Indonesische grammatica; Van klassiek naar modern Maleis (Leiden, 1951), Bijdragen tot de Taal-, Landen Volkenkunde 108:205-6. 
1952b [Review of:] P.J. Zoetmulder, De taal van het Adiparwa; Een grammaticale studie van het Oudjavaans (Bandung, 1950), Bijdragen tot de Taal-, Land-en Volkenkunde 108:305-11.

1952c [Review of:] A.W. de Groot, Structurele syntaxis (Den Haag, 1949), Museum 57:66-8.

1953

1953a 'The study of word classes in Javanese', Lingua 3:322-54. [Revised version in 1978a:40-68.]

1953b 'Woordverdubbeling in het Javaans' [Word duplication in Javanese], Bijdragen tot de Taal-, Land-en Volkenkunde 109:52-61. [Revised English version in 1978a:89-97.]

1953c 'De systematiek der Javaanse telwoorden' [The Javanese numeral system], Bijdragen tot de Taal-, Land- en Volkenkunde 109:342-75. [Revised English version in 1978a:176-209.]

1953d 'Het aandeel van phonetiek en phonologie in het onderzoek van onbekende talen' [The contribution of phonetics and phonology to the study of unknown languages], Nederlandse Vereniging voor Phonetische Wetenschappen. Verslagen van vergaderingen in 1953 (1953):12-5.

1954

1954a 'Verdubbelingsprocédé's bij het Javaanse werkwoord' [Duplication in the morphology of the Javanese verb], Bijdragen tot de Taal-, Landen Volkenkunde 110:369-87. [Revised English version in 1978a:98116.]

1954b 'The analysis of the phoneme in distinctive features and the process of hearing', Lingua 4:167-93. [With H. Mol.]

1954c [Review of:] Bibliographie linguistique de l'année 1951 et complément des années précédentes (Utrecht, 1954), Museum 59:145.

1955

1955a Over woordvorming in het Javaans [On word formation in Javanese], Bijdragen tot de Taal-, Land- en Volkenkunde 111:286-307. [Revised English version in 1978a: 69-88].

1955b 'The linguistic relevance of intensity in stress', Lingua 5:205-13. [With H. Mol.]

1955c [Review of:] W. Porzig, Das Wunder der Sprache (München, 1950), Museum 60:17-9.

1955d [Review of:] I. Dyen, Proto-Malayo-Polynesian laryngeals (Baltimore, 1953), Lingua 5:308-18. 
1956

1956a 'Verb structure in Javanese', in: M. Halle, H.G. Lunt, H. McLean and C.H. van Schooneveld (eds), For Roman Jakobson; Essays on the occasion of his sixtieth birthday, 11 October 1956, pp. 567-73. The Hague: Mouton. [Revised version in 1978a:117-26.]

1956b 'De studie der zgn. exotische talen in verband met de algemene taalwetenschap' [The study of the so-called exotic languages and general linguistics], Museum 61:65-80. [Revised English version: 1960d.]

1956c 'Taalwetenschap' [Linguistics], in: E.J. Dijksterhuis (ed.), Scientia; Handboek voor wetenschap, kunst en religie. Vol. 1, pp. 258-75. Zeist: De Haan. Three vols.

1956d 'Het onderzoek der intonatie-verschijnselen' [The study of intonational phenomena], in: Handelingen van het vierentwintigste Nederlands filologencongres gehouden te Amsterdam op 5 en 6 April 1956, pp. 77-8. Groningen: Wolters.

1956d [Review of:] P. Guiraud, Bibliographie critique de la statistique linguistique (Utrecht, 1954), Lingua 6:203-9.

1956e [Review of:] J.B. Carroll, The study of language; A study of linguistics and related disciplines in America (Cambridge, Mass., 1953), Romance Philology 10:343-7.

1956 [Review of:] Bibliographie linguistique de l'année 1952 et complément des années précédentes (Utrecht, 1955); Bibliographie linguistique de l'année 1953 et complément des années précédentes (Utrecht, 1956), Museum 61: 81-2.

1957

1957a 'The correlation between interpretation and production of speech sounds', Lingua 6:333-53. [With H. Mol.]

$1957 \mathrm{~b}$ 'Some impressions of the 8th International Congress of Linguists held in Oslo, Norway, August 5-9, 1957', Lingua 7:87-98. [With A.W. de Groot.]

1958

1958a Critical survey of studies on the languages of Borneo. 's-Gravenhage: Nijhoff, iv+92 pp. [KITLV, Bibliographical Series 2.] [With A.A. Cense.]

1958b 'Traditionele zinsontleding en syntaxis' [Traditional parsing and syntax], Levende Talen 193:18-30.

1958c 'Over de interpretatie van de Nāgarakṛtāgama' [On the interpretation of the Nāgarakṛtāgama], Bijdragen tot de Taal-, Land- en Volkenkunde 114:210-37. [With A. Teeuw.]

1958d 'De noodzaak van het vertalen' [The need for translation], Museum 63:225-36. [With S. Dresden; reprinted as 1996d.] 
1958e 'De universitaire studie in de zgn. moderne talen' [The university study of the so-called modern languages], Universiteit en Hogeschool 4:258-65.

1959

1959a Taalwetenschap; Een eerste inleiding [Linguistics; A first introduction]. 's-Gravenhage: Smits, 47 pp. [Revised and expanded version of 1956c.]

1959b 'Syntaxis te Sappemeer' [Syntax at Sappemeer], De Nieuwe Taalgids 52:222-3.

1959c 'Hearing and the concept of the phoneme', Lingua 8:161-85. [With $\mathrm{H}$. Mol.]

1959d 'Die mit javanisch rasa morphologisch zusammenhängenden Wörter; Ein Beitrag zur javanischen Lexikologie', Oriens Extremus 6:104-15. [Revised English version in 1978a:161-75.]

1959e [Review of:] M. Joos (ed.), Readings in linguistics; The development of descriptive linguistics in America since 1925 (Chicago, 1957), Lingua 8:327-9.

1960a Aantekeningen bij Tjan Tjoe Siem's vertaling van de Lakon Kurupati Rabi [Notes on Tjan Tjoe Siem's translation of the Lakon Kurupati Rabi.] 's-Gravenhage: Nijhoff, viii+67 pp. [KITLV, Verhandelingen 29.]

1960b De systematiek der Javaanse pronomina [The Javanese pronominal system]. 's-Gravenhage: Nijhoff, viii+63 pp. [KITLV, Verhandelingen 30.] [English version in 1978a:210-77.]

1960c Taalwetenschap; Een eerste inleiding [Linguistics; A first introduction]. Tweede druk. 's-Gravenhage: Smits, 47 pp. [Second revised edition of 1959a.]

1960d 'The study of the so-called exotic languages and general linguistics', Lingua 9:417-34. [English version of 1956b.]

1960e 'Moderne Nederlandse taalbeschrijving; Een critiek [Modern Dutch language description; A critique], Forum der Letteren 1:56-69.

$1960 \mathrm{f}$ [Review of:] M.E.J.G. Verstraelen, De bijwoordelijke bepalingen van het werkwoord in enkele Indonesische talen (Utrecht, 1955), Bijdragen tot de Taal-, Land- en Volkenkunde 116:388-90.

$1960 \mathrm{~g}$ [Review of:] A. Capell, A linguistic survey of the South-Western Pacific (Nouméa, 1957), Bijdragen tot de Taal-, Land- en Volkenkunde 116:391-2.

1960h [Review of:] C. Maxwell Churchward, Tongan grammar (Oxford, 1953); Tongan dictionary (Oxford, 1955), Bijdragen tot de Taal-, Land-en Volkenkunde 116:392.

1960i [Review of:] H.R. Klieneberger, Bibliography of Oceanic linguistics (London, 1957), Bijdragen tot de Taal-, Land-en Volkenkunde 116:393. 
1961a Taalwetenschap; Een eerste inleiding [Linguistics; A first introduction]. Derde druk. 's-Gravenhage: Smits, $47 \mathrm{pp}$. [Third revised editon of 1960c.]

1961b 'Het 10de Pacific Science Congress van 21 augustus tot 6 september te Honolulu gehouden', Bijdragen tot de Taal-, Land-en Volkenkunde 117:475-8.

1962

1962a 'Enige kanttekeningen bij Lochers artikel over Lévi-Strauss' [Some comments on Locher's article on Lévi-Strauss], Forum der Letteren 3:48-53.

1962b 'Limitations of morphological processes; Some preliminary remarks', Lingua 11:426-32.

1962c 'De beginselen van het syntactisch onderzoek' [The basic principles of syntactic research], in: A.B.J.N. Reichling [et al.], Taalonderzoek in onze tijd, pp. 17-37. Den Haag: Servire. [Reprinted as 1968f.]

1963

1963a 'An appraisal of transformation theory', Lingua 12:1-18. [Reprinted in 1973a:1-18.]

$1963 \mathrm{~b}$ 'The comparative study of the Austronesian languages', in: H.L. Shorto (ed.), Linguistic comparison in South East Asia and the Pacific, pp. 24-27. London: School of Oriental and African Studies, University of London.

1963c 'Albert Willem de Groot, 13 Jan. 1892 - 14 Dec. 1963', Lingua 12:22932. [With W. Sydney Allen and A.B.J.N. Reichling.]

1963d [Review of:] E.C. Horne, Beginning Javanese (New Haven, 1961), Lingua 12:69-86.

1963e [Review of:] A.J.J. de Witte and N.C.H. Wijngaards, De struktuur van het Nederlands ('s-Hertogenbosch, 1961), Levende Talen 220:411-20.

1964

1964a A critical survey of studies on the languages of Java and Madura. 's-Gravenhage: Nijhoff, viii+207 pp. [KITLV, Bibliographical Series 7.]

1964b 'Betekenis en syntaxis' [Meaning and syntax], Forum der Letteren 5:67-82. [Reprinted as 1968g.]

1964c 'Fundamentals of syntax', in: H.G. Lunt (ed.), Proceedings of the 9th International Congress of Linguists, Cambridge, Mass., August 27-31, 1962, pp. 166-71. The Hague: Mouton. [With A.B.J.N. Reichling.]

1964d 'Commentaar' [Comment on article by C. Kruyskamp on Dutch spelling in NRC], Forum der Letteren 5:91-4. 
1965

1965a Taalwetenschap; Een eerste inleiding [Linguistics; A first introduction]. Vierde druk. 's-Gravenhage: Smits, $60 \mathrm{pp}$. [Fourth revised and expanded edition of 1961a.]

1965b 'Some preliminary remarks on Javanese syntax', Lingua 15:53-70.

1965c 'On Melanesian and the origin of Austronesian; Some comments on Capell's "Oceanic linguistics to-day"', Current Anthropology 6:222-3. [With J.C. Anceaux.]

1965d [Review of:] C. Mohrmann, A. Sommerfelt and J. Whatmough (eds), Trends in European and American linguistics 1930-1960 (Utrecht, 1961), Romance Philology 19:353-60.

1966

1966a 'Enige beschouwingen over Amerikaanse en Nederlandse linguïstiek' [Some considerations on American and Dutch linguistics], Forum der Letteren 7:1-22.

1966b 'Substantief + substantief in Modern Algemeen Nederlands' [Noun + noun in Standard Modern Dutch], De Nieuwe Taalgids 59:291-301. [Reprinted as 1968h; see also 1970i.]

1966c 'The structure of the Javanese morpheme', in: E.P. Hamp, F.W. Householder and R. Austerlitz (eds), Readings in linguistics II, pp. 248-70. Chicago: University of Chicago Press. [Reprint of 1950b.]

1967

1967a 'Indonesia and Malaysia', in: Th.A. Sebeok (ed.), Current trends in linguistics; Vol. 2: Linguistics in East Asia and South-East Asia, pp. 847-98. The Hague: Mouton.

1967b 'Some further remarks on transformational grammar', Lingua 17: 263-316. [Reprinted in 1973a:19-75; Russian translation: 1968e.]

1967c 'Language in action', in: R. Abernathy [et al.], To honor Roman Jakobson; Essays on the occasion of his seventieth birthday, 11 October 1966, pp. 2060-6. The Hague: Mouton.

1967d 'Perspectief der Nederlandse Oriëntalistiek' [The prospect of Dutch Oriental studies], Bijdragen tot de Taal-, Land-en Volkenkunde 123:20516. [Japanese translation: 1969e.]

1967e 'In Dresdens Wereld in woorden' [On S. Dresden, Wereld in woorden; Beschouwingen over romankunst, 1965], Forum der Letteren 8:55-62.

$1967 f$ [Review of:] G. Mounin, Les problèmes théoriques de la traduction, Lingua 18:196-206.

$1967 g$ [Review of:] J. Vachek and E. Pauliny (eds), L'École de Prague aujourd'hui. (Prague, 1964), Lingua 17:358-65. 
1967h [Review of:] Theodore G.Th. Pigeaud, Literature of Java; Catalogue raisonné of Javanese manuscripts in the Library of the University of Leiden and other public collections in the Netherlands. Vol. 1: Synopsis of Javanese literature, 900-1900, A.D. (The Hague, 1967), Forum der Letteren 8:231-3.

$1967 \mathrm{i}$ [Review of:] G.F. Bos and H. Roose (eds), Betekenis en woordstructuur; Nagelaten geschriften van Prof. Dr. A.W. de Groot (Groningen, 1966), Forum der Letteren 8:233-40.

1968

1968a Taalwetenschap; Een eerste inleiding [Linguistics; A first introduction]. Vijfde druk. 's-Gravenhage: Smits, 72 pp. [Fifth revised and expanded edition of 1965a.]

1968b 'Some impressions of the 10th International Congress of Linguists', Lingua 19:225-32. [With S.C. Dik and J.G. Kooij.]

1968c 'Personal pronouns and pronominal suffixes in Old Javanese', Lingua 21:466-82.

1968d 'Taalonderwijs en taalonderzoek' [Language teaching and language research], Forum der Letteren 9:65-80. [See also 1970f.]

1968e 'Ešče raz o transformacionnoj grammatike' [Some further remarks on transformational grammar], Voprosy Jazykoznanija 3:94-111, 4:10716. [Russian translation of 1967b.]

$1968 \mathrm{f}$ 'De beginselen van het syntactisch onderzoek' [The basic principles of syntactic research], in: J. Hoogteijling (ed.), Taalkunde in artikelen, pp. 24-43. Groningen: Wolters-Noordhoff. [Reprint of 1962c.]

$1968 \mathrm{~g}$ 'Betekenis en syntaxis' [Meaning and syntax], in: J. Hoogteijling (ed.), Taalkunde in artikelen, pp. 44-59. Groningen: Wolters-Noordhoff. [Reprint of 1964b.]

1968h 'Substantief + substantief in Modern Algemeen Nederlands' [Noun + noun in Standard Modern Dutch], in: J. Hoogteijling (ed.), Taalkunde in artikelen, pp. 175-85. Groningen: Wolters-Noordhoff. [Reprint of 1966b.]

1969

1969a 'Nouns from verb bases; A transpositional category in Standard Javanese', in: A.G. Sciarone, A.J. van Essen and A.A. van Raad (eds), Nomen; Leyden studies in linguistics and phonetics, pp. 178-90. The Hague: Mouton. [Revised version in 1978a:150-60.]

$1969 \mathrm{~b}$ 'On the notion of "completely novel sentences"', Cahiers Ferdinand de Saussure 26:179-86. [Reprinted in 1973a:76-83.]

1969c 'Systematic features of Javanese personal names', Word 25:321-35. [Revised version in 1978a:336-51.] 
1969d 'Studie van taalfunctiestoornissen te Leiden zonder taalfunctiedeskundigen' [The study of language disorders at Leiden without language experts], Forum der Letteren 10:55-6.

1969e [Review of:] A. van Gennep, The semi-scholars, Bijdragen tot de Taal-, Land- en Volkenkunde 125:157.

$1969 f$ [Review of:] A. Teeuw, Modern Indonesian literature ('s-Gravenhage, 1967), Forum der Letteren 10:58-9.

1970

1970a Taalwetenschap; Een eerste inleiding [Linguistics; A first introduction]. Zesde druk. 's-Gravenhage: Smits, 80 pp. [Sixth revised and expanded edition of 1968a.]

$1970 \mathrm{~b}$ 'The dynamic nature of word meaning', in: A. Graur [et al.] (eds), Actes du Xe Congrès International des Linguistes, Bucarest, 28 août - 2 septembre 1967. Vol. 2, pp. 679-84. Bucarest: Académie de la République Socialiste de Roumanie.

1970c 'Facts and theory in the study of the so-called adverbs and adverbials in present-day English', in: Jean Dierickx and Yvan Lebrun (eds), Linguistique contemporaine; Hommage à Éric Buyssens, pp. 253-60. Bruxelles: Institut de Sociologie.

1970d 'Position and syntactic function of the particle $t a$ in Old Javanese', in: Roman Jakobson and Shigeo Kawamoto (eds), Studies in general and Oriental linguistics presented to Shirô Hattori on the occasion of his sixtieth birthday, pp. 648-58. Tokyo: TEC Corporation for Language and Educational Research.

1970e 'The use of respect forms in Javanese', in: S.A. Wurm and D.C. Laycock (eds), Pacific linguistic studies in honour of Arthur Capell, pp. 44166. Canberra: Australian National University. [Pacific Linguistics, C13.] [Revised version in 1978a:300-20.]

$1970 \mathrm{f}$ 'Taalwetenschap en taalonderwijs' [Linguistics and language teaching], Forum der Letteren 11:94-9. [See also 1968d.]

$1970 \mathrm{~g}$ 'The need for transparency in language description'. Paper, Burg Wartenstein Symposium no. 49: Toward the description of the languages of the world, August 1-8, 1970. New York: Wenner-Gren Foundation for Anthropological Research, 21 pp.

1970h 'The Javanese verb system', in: A. Gosh [et al.] (eds), Proceedings of the 26th International Congress of Orientalists, New Delhi, 4-10 January 1964. Vol. 4, pp. 79-84. New Delhi: Organising Committee XXVI International Congress of Orientalists. [Revised version in 1978a: 127-35.]

1970i 'Post-scriptum', De Nieuwe Taalgids 63:114-5. [Postscript to 1966b.]

1970j [Review of:] Robert Abernathy [et al.], To honor Roman Jakobson; Essays on the occasion of his seventieth birthday, 11 October 1966 (The Hague, 1967), Forum der Letteren 11:71-5. 
1971a Nové výsledky vývoje transformační generativní gramatiky' [Recent developments in transformational-generative grammar], Slovo a Slovesnost 32:1-19, 117-39. [English version in 1973a:84-134.]

$1971 b$ 'Peripheral verb categories with emotive-expressive or onomatopoeic value in Modern Javanese', Travaux Linguistique de Prague 4:145-56. [Revised version in 1978a:136-49.]

1971c 'Kraak's negatieve zinnen; Een laat antwoord' [Kraak's negative sentences; A late response], Forum der Letteren 12:100-34.

1971d 'Indonesia and Malaysia', in: Thomas A. Sebeok (ed.), Current trends in linguistics. Vol. 8: Linguistics in Oceania, pp. 55-111. The Hague: Mouton.

1971e 'The languages of Indonesia; Past, present and future', Southeast Asia 1:209-21.

1972

1972a Taalwetenschap; Een eerste inleiding [Linguistics; A first introduction]. Zevende druk. 's-Gravenhage: Smits, $92 \mathrm{pp}$. [Seventh revised and expanded edition of 1970a.]

1972b [Review of:] P.E. de Josselin de Jong, Contact der continenten; Een bijdrage tot het begrijpen van niet-westerse samenlevingen (Leiden, 1969), Bijdragen tot de Taal-, Land-en Volkenkunde 128:148-51.

1973

1973a Critical comments on transformational-generative grammar 1962-1972. The Hague: Smits, viii+171 pp. [Contains 1963a, 1967b, 1969b, 1973b and an English translation of 1971a.]

1973b 'Semantic representation and word meaning', in: 1973a: 135-57.

1973c 'Het universitair onderwijs in de moderne vreemde talen' [University education in modern foreign languages], Levende Talen 300:42945. [With T.J.M. van Els.]

1974

1974 'Structurele taalwetenschap' [Structural linguistics], in: F. Balk-Smit Duyzentkunst [et al.], Controversen in de taal-en literatuurwetenschap, pp. 137-68. Wassenaar: Servire.

1975a Taalkunde en sociale wetenschappen [Linguistics and social sciences]. Amsterdam: Noord-Hollandsche Uitgeversmaatschappij, 44 pp. [Koninklijke Nederlandse Akademie van Wetenschappen, Sociaal-Wetenschappelijke Raad, Werkdocumenten 4.] [With H.C.J. Duijker.] 
1975b 'De interpretatie van de Oud-Javaanse Rāmāyaṇa-kakawin; Enige algemene beschouwingen en gezichtspunten' [The interpretation of the Old Javanese Rāmāyana-kakawin; Some general considerations and perspectives], Bijdragen tot de Taal-, Land-en Volkenkunde 131:195-213.

1975c 'Sentence segment and word group, basic concepts of Javanese syntax', in: John W.M. Verhaar (ed.), Miscellaneous studies in Indonesian and languages in Indonesia. Vol. 1, pp. 6-10. Jakarta: Badan Penyelenggara Seri NUSA.

1975d 'Transformational-generative grammar and the teaching of foreign languages; A critical appraisal', in: A.J. van Essen and J.P. Menting (eds), The context of foreign-language learning, pp. 152-8. Assen: Van Gorcum.

1975e 'Wetenschapsbeleid and geesteswetenschappelijk onderzoek' [Science policy and research in the humanities], in: W. de Vroomen (ed.), Geesteswetenschappelijk onderzoek, pp. 15-27. Den Haag: Smits. [English version: 1976d; see also 1976e.]

$1975 \mathrm{f}$ 'Aspecten van het wetenschapsbeleid' [Aspects of research policy]. Koninklijke Nederlandse Akademie van Wetenschappen, Verslag Bijzondere zitting van de beide afdelingen op 24 mei 1975, pp. 9-18. Amsterdam: Noord-Hollandsche Uitgeversmaatschappij.

1975g 'Meer aandacht voor de Nederlandse graduate school' [More attention to the Dutch graduate school], in: Niet bij wetenschap alleen ... Liber amicorum aangeboden aan dr. A. J. Piekaar bij zijn afscheid als directeur-generaal van het Ministerie van Onderwijs en Wetenschappen op 27 februari 1975, pp. 134-40. Den Haag: Ministerie van Onderwijs en Wetenschappen.

1975h 'Een zwarte dag voor de didactiek in Leiden' [A black day for didactics in Leiden], Forum der Letteren 16:66-9.

1975i 'De Romaanse talen in Illinois' [Romance languages in Illinois], Forum der Letteren 16:249-50. [Comment on W.R. Cantrall, Viewpoint, reflexives, and the nature of noun phrases, The Hague, 1974.]

1975j 'Niet ter diskussie in de taalwetenschap?' [Not for discussion in linguistics?], Forum der Letteren 16:250-1, [Comment on G.J. de Haan, G.A.T. Koefoed and A.L. des Tombe, Basiscursus algemene taalwetenschap, Assen, 1974.]

1975k 'Onderzoek van onderzoek van onderwijs gewenst' [The need for the inspection of school inspections], Forum der Letteren 16:251-2.

19751 'Professor Freudenthal's kleinzoontje verdedigd tegen zijn grootvader' [In defence of Professor Freudenthal's grandson against his grandfather], Forum der Letteren 16:253-4. [Comment on misconceptions about language learning.] 
1975m 'Wanbegrip over aard en functie van de Oriëntalistiek' [Misconception about the nature and function of Oriental studies], NRC Handelsblad 7 Juni 1975. [Letter to the editor.]

1976

1976a Taal en taalwetenschap [Language and linguistics]. Leiden: Universitaire Pers, 20 pp. [Dies natalis lecture at Leiden University.]

1976b Taalwetenschap; Een eerste inleiding [Linguistics; A first introduction]. Achtste druk. 's-Gravenhage: Smits, 100 pp. [Eighth revised and expanded edition of 1972a.]

1976c 'Javanese kinship and forms of respect', Archív Orientální 44:253-66. [Revised version in 1978a:321-35.]

1976d 'Science policy and research in the humanities', in: W. de Vroomen (ed.), Research policy in the humanities of the Netherlands, pp. 23-32. 's-Gravenhage: Staatsuitgeverij. [English translation of 1975e.]

1976e 'Wetenschapsbeleid en geesteswetenschappelijk onderzoek' [Science policy and research in the humanities], in: W. Hutter [et al.] (eds), Op weg naar criteria voor onderzoeksbeleid, pp. 136-41. Groningen: Wolters-Noordhoff. [See also 1975e.]

1977

1977a 'Roman Jakobson and Dutch linguistics', in: D. Armstrong and C.H. van Schooneveld (eds), Roman Jakobson; Echoes of his scholarship, pp. 485-502. Lisse: De Ridder.

$1977 \mathrm{~b}$ 'The concepts of productivity and potentiality in morphological description and their psycholinguistic reality', in: G. Drachman (ed.), Akten der 3. Salzburger Jahrestagung für Linguistik (Psycholinguistik) 1976, pp. 379-92. Salzburg: Neugebauer.

1977c 'Nederlandse voorlichting over generatieve grammatica' [Dutch information on generative grammar], Forum der Letteren 18:167-210.

1978

1978a Studies in Javanese morphology. The Hague: Nijhoff. [KITLV, Translation Series 19.] [Contains revised (translated) versions of 1950a, 1950b, 1953a, 1953b, 1953c, 1954a, 1955a, 1956a, 1959d, 1960b, 1969a, 1969c, 1970e, 1970h, 1971b, 1976c; Indonesian translation: 1982c.]

$1978 \mathrm{~b}$ 'On the distinction between linguistics and pragmatics', in: David Gerver and H. Wallace Sinaiko (eds), Language interpretation and communication, pp. 185-98. New York: Plenum.

1978c 'A classical case of structural ambiguity or no ambiguity at all?', in: Mohammad Ali Jazayeri, Edgar C. Polomé and Werner Winter (eds), Linguistic and literary studies in honor of Archibald A. Hill. Vol. 2: Descriptive linguistics, pp. 121-5. The Hague: Mouton. 
1978d 'The communicative function of language and speech', in: Frank Coppieters and Didier L. Goyvaerts (eds), Functional studies in language and literature, pp. 109-17. Ghent: Story-Scientia.

1979a 'Linguistics in America 1924-1974; A detached view', in: Henry M. Hoenigswald (ed.), The European background of American linguistics; Papers of the Third Golden Anniversary Symposium of the Linguistic Society of America, December 27, 1974, pp. 121-44, 153-7. Dordrecht: Foris.

1979b 'Hoe een linguïst omgaat met ambassadrices en masseuses; Een kritische vergelijking van morfologische theorie en descriptieve praktijk' [How a linguist deals with embassadresses and masseuses; A critical comparison of morphological theory and descriptive practice], in: Teun Hoekstra and Harry van der Hulst (eds), Morfologie in Nederland, pp. 7-20. Leiden: Glot Special.

1979c 'Schriftelijk en mondeling taalgebruik; Een poging tot analyse van hun fundamentele verschillen' [Written and oral usage. An attempt at analyzing their fundamental differences], Forum der Letteren 20:405-11.

1980

1980a Het wonder van de natuurlijke taal [The wonder of natural language]. Haarlem: Hollandsche Maatschappij der Wetenschappen, 27 pp. [Haarlemse Voordrachten 40.]

1980b Taalwetenschap; Een eerste inleiding [Linguistics; A first introduction]. Negende druk. 's-Gravenhage: Smits, 116 pp. [Ninth revised and expanded edition of 1976b.]

1980c 'Language universals, individual language structure, and the Lingua descriptive series project', in: Günter Brettschneider and Christian Lehmann (eds), Wege zur Universalienforschung; Sprachwissenschaftliche Beiträge zum 60. Geburtstag von Hansjakob Seiler, pp. 59-64. Tübingen: Narr.

1980d 'Observation in semantics is not easy', in: D.J. van Alkemade, A. Feitsma, W.J. Meys and P. van Reenen (eds), Linguistic studies offered to Berthe Siertsema, pp. 127-35. Amsterdam: Rodopi.

1981

1981a Betekenis in lingü̈stisch perspectief [Meaning in linguistic perspective]. Amsterdam: Noord-Hollandsche Uitgeversmaatschappij, 24 pp. [Mededelingen der Koninklijke Nederlandse Akademie van Wetenschappen, Afdeling Letterkunde, Nieuwe Reeks 44, 8.]. [= 1981b.] 
1981b 'Betekenis in linguïstisch perspectief' [Meaning in linguistic perspective]. Medelingen der Koninklijke Nederlandse Akademie van Wetenschappen, Afdeling Letterkunde, Nieuwe Reeks 44, 339-360.

1981c 'First principles in the study of language', in: J. Barbizet [et al.] (ed.), Comprendre le langage; Actes du colloque international et multidisciplinaire sur la compréhension du langage, Créteil 25-27 septembre 1980: le point de vue des linguistes, le point de vue des traducteurs interprètes, le point de vue des neuropsychologues, pp. 86-8. Paris: Didier.

1981d 'Language and linguistics in (Dutch) structural anthropology', in: Gretchen A. Moyer, David S. Moyer and P.E. de Josselin de Jong (eds), The nature of structure, pp. 79-94. Leiden: Institute of Cultural and Social Studies.

1981e 'Productivity and creativity; Some remarks on the dynamic aspects of language', in: W. Dietrich [et al.] (eds), Logos semantikos; Studia linguistica in honorem Eugenio Coseriu 1921-1981. Vol. 3: Semantik, pp. 165-74. Berlin: De Gruyter, Madrid: Gredos.

$1981 \mathrm{f}$ [Review of:] 'A sad case of lack of scholarly communication; An American introduction to Old Javanese', Bijdragen tot de Taal-, Land-en Volkenkunde 137:347-62. [M.S. Zurbuchen, Introduction to Old Javanese language and literature; A Kawi prose anthology, Ann Arbor, 1976.]

1982

1982a Computers in het onderwijs [Computers in education]. 's-Gravenhage: Staatsuitgeverij, 20 pp. [With N.G. de Bruijn and W.J.M. Levelt.]

1982b Ilmu bahasa; Pengantar dasar [Linguistics; A first introduction]. Jakarta: Djambatan, ix+90 pp. [Indonesian translation of 1959a.]

1982c Kajian morfologi bahasa Jawa [Studies in Javanese morphology]. Jakarta: Djambatan, xiv+417 pp. [Indonesian translation of 1978a.]

1982d 'Enige beschouwingen over verleden, heden en toekomst van de taalwetenschap in Nederland' [Some reflections on the past, present and future of linguistics in The Netherlands], Forum der Letteren 23:163-83.

1983a Javanese linguistics; A retrospect and some prospects: Lecture delivered on the occasion of the Fourth European Colloquium on Malay and Indonesian Studies on Tuesday May 31, 1983. With a foreword by A. Teeuw. Dordrecht: Foris, Leiden: Koninklijk Instituut voor Taal-, Land- en Volkenkunde, 24 pp.

1983b Linguistics: neither psychology nor sociology. Uhlenbeck-Lecture, 1. Wassenaar: NIAS, 24 pp. 
1983c 'Two mechanisms of Javanese syntax; The construction with sing (kang, ingkang) and with olehe (ĕnggone, anggenipum)', in: Amran Halim, Lois Carrington and S.A. Wurm (eds), Papers from the Third International Conference on Austronesian Linguistics. Vol. 4: Thematic variation, pp. 9-20. Canberra: Department of Linguistics, Research School of Pacific Studies, Australian National University.

1983d 'Why do all languages have a syntax? The instrumental relationship between syntax and semantics', in: S. Rot (ed.), Languages in function. Materials of the XIIIth Annual Conference of the Societas Linguistica Europaea, held in Budapest, 3-6.IX.1980, pp. 291-9. Budapest: Sokszorosító.

1983e [Review of:] Tjan Tjoe Siem, Javaansche kaartspelen; Bijdrage tot de beschrijving van land en volk (Bandoeng, 1941), Bijdragen tot de Taal-, Land-en Volkenkunde 139:348-56.

$1983 \mathrm{f}$ Introduction to: P.J. Zoetmulder, De taal van het Adiparwa; Een grammaticale studie van het Oudjavaans, pp. v-vi. Dordrecht: Foris. [Koninklijk Instituut voor Taal-, Land- en Volkenkunde.]

1984

1984a 'Synthesis and evaluation', in: C. Reedijk, Carol K. Henry and W.R.H. Koops (eds), Large libraries and new technological developments; Proceedings of a symposium held on the occasion of the inauguration of the new building of the Royal Library, The Hague, 29 September - 1 October 1982, pp. 179-87. München: Saur.

1984b Preface and introduction to: F.S. Eringa, Soendaas-Nederlands woordenboek, pp. vii-x; xi-xii. Dordrecht: Foris. [Koninklijk Instituut voor Taal-, Land- en Volkenkunde.]

1985

1985a 'The linguistic senselessness of the concept of nonsense-sentences', International Journal of American Linguistics 51:602-4.

1985 b 'John opened the door with the key; Some remarks on case, semantic role and word meaning', in: Ursula Pieper and Gerhard Stickel (eds), Studia linguistica diachronica et synchronica; Werner Winter sexagenario anno MCMLXXXIII gratis animis ab eius collegis, amicis discipulisque oblata, pp. 829-40. Berlin: Mouton de Gruyter.

1985c 'The concept of proportionality, Old Javanese, morphology and the structure of the Old Javanese word kakawin', in: Sulastin Sutrisno, Darusuprapta and Sudaryanto (eds), Bahasa, sastra, budaya; Ratna manikam untaian persembahan kepada Prof. Dr. P.J. Zoetmulder, pp. 6682. Yogyakarta: Gadjah Mada University Press. 
1986

1986a De niet-westerse studies in Nederland; Een verkenning. [Non-western studies in the Netherlands; A survey]. Zoetermeer: Ministerie van Onderwijs en Wetenschappen.

1986b 'Clitic, suffix, and particle; Some indispensable distinctions in Old Javanese grammar', in: C.M.S. Hellwig and S.O. Robson (eds), A man of Indonesian letters; Essays in honour of Professor A. Teeuw, pp. 334-41. Dordrecht: Foris. [KITLV, Verhandelingen 121.]

1986c 'De Jong over Balai Pustaka; Een kritisch commentaar' [De Jong on Balai Pustaka. A critical comment], Bijdragen tot de Taal-, Land-en Volkenkunde 142:337-41. [Comment on L. de Jong, Het Koninkrijk der Nederlanden in de Tweede Wereldoorlog. Deel 11b. Nederlands-Indië, 's-Gravenhage, 1985.]

1987

1987a 'Sentence patterns in the Old Javanese of the Parwa literature', in: Donald C. Laycock and Werner Winter (eds), A world of language; Papers presented to Professor S.A. Wurm on his 65th birthday, pp. 695708. Canberra: Department of Linguistics, Research School of Pacific Studies, Australian National University.

1987b 'Functioneel-structurele morfologie versus generatieve morfologie' [Structural-functional morphology versus generative morphology], Forum der Letteren 28:115-22.

1988

1988 'Anton Reichling. Nijmegen 9 juli 1898 - Amsterdam 25 mei 1986', Jaarboek van de Maatschappij der Nederlandse Letterkunde te Leiden (1986-87):110-20.

1989a 'The problem of interpolation in the Old Javanese Rāmāyaṇa kakawin', Bijdragen tot de Taal-, Land-en Volkenkunde 145:324-35.

1989b 'Gebrekkige voorlichting' [Inadequate information], Forum der Letteren 30:50-3. [Comment on L. Koenen and G. de Graaf, Vanzelfsprekend, Utrecht, 1988.]

1990 'Clitics, morphemes, and words; Their structural differences', in: W. Bahner, J. Schildt and D. Viehweger (eds), Proceedings of the 14th International Congress of Linguists, Berlin / GDR, August 10 - August 15, 1987, pp. 637-41. Berlin: Akademie-Verlag. 
1991

1991a Endangered languages. Oxford: Berg, xiv+273 pp. [Co-edited with R.H. Robins.]

1991b Preface to 1991a, pp. xiii-xiv.

1991c 'Linguistics, interpretation, and the study of literature', in: J.J. Ras and S.O. Robson (eds), Variation, transformation and meaning; Studies on Indonesian literatures in honour of A. Teeuw, pp. 17-36. Leiden: KITLV Press. [Verhandelingen 144.]

1991d 'Nouns, nominal groups, and substitutional processes in Old Javanese', in: Ray Harlow (ed.), Western Austronesian and contact languages. Papers from the Fifth International Conference on Austronesian Linguistics, pp. 349-66. Auckland: Linguistic Society of New Zealand, University of Auckland. [VICAL 2.]

1991e 'Cornelis Christiaan Berg, 18 december 1900 - 25 juni 1990', Jaarboek van de Koninklijke Nederlandse Akademie van Wetenschappen (1991):1316.

$1991 f$ [Review of:] S. Daalder and J. Noordegraaf (eds), H.J. Pos (18981955), taalkundige en geëngageerd filosoof (Amsterdam, 1990), Ons Erfdeel 34:464-5.

1992

1992a 'Words', in: William Bright (ed.), International encyclopedia of linguistics. Vol. 4, pp. 246-8. New York: Oxford University Press.

1992b 'General linguistics and the study of morphological processes', Oceanic Linguistics 31:1-11.

1992c 'Pražské inspirace v mém jazykovědném myšlení' [Prague inspiration in my linguistic thinking], Slovo a Slovesnost 53:81-5.

1992d 'Antonymic processes within the system of Javanese adjectives', in: Tom Dutton, Malcolm Ross and Darrell Tryon (eds), The language game; Papers in memory of Donald C. Laycock, pp. 491-500. Canberra: Department of Linguistics, Research School of Pacific Studies, Australian National University.

1992e 'Some critical remarks on a recent interpretation of a sentence from the Old Javanese Tantri Kamandaka', Bijdragen tot de Taal-, Landen Volkenkunde 148:262-9. [Comment on A.L. Becker, 'Binding wild words; Cohesion in Old Javanese prose', in: H. Kridalaksana and A.M. Moeliono (eds), Pelangi bahasa; Kumpalan esai yang dipersembahkan kepada Prof. Dr. J.W.M. Verhaar, S.J., pp. 19-36. Jakarta: Bhratara Karya Aksara.]

$1992 \mathrm{f}$ 'Distinctions in the study of linguistic semantics', in: Astri Heen Wold (ed.), The dialogical alternative; Towards a theory of language and mind, pp. 273-91. Oslo: Scandinavian University Press. 
1993a 'De dreiging van snelle taalsterfte, een sinds kort onderkend mondiaal probleem' [The threat of rapid language death, a recently acknowledged global problem], Ons Erfdeel 36:23-32.

$1993 \mathrm{~b}$ 'The threat of rapid language death, a recently acknowledged global problem', The Low Countries; Arts and society in Flanders and the Netherlands: A Yearbook, 1993-1994, pp. 25-31. Brugge: Stichting Ons Erfdeel. [English translation of 1993a.]

1993c 'Talen zonder grenzen' [Languages without frontiers]; Verslag van een conferentie door de Verkenningscommissie Moderne Letteren op 23 oktober 1992', Ons Erfdeel 36:786-7.

1994

1994a 'The birth of NIAS', in: W.R. Hugenholtz (ed.), 22 1/2 years of NIAS, pp. 15-24. Wassenaar: NIAS, Netherlands Institute for Advanced Study in the Humanities and Social Sciences.

1994b 'De positie van woord en zin in taal en taalwetenschap' [The position of the word and sentence in language and linguistics], Neerlandica Extra Muros 32-2:1-9.

1994c 'Functional sentence perspective in Modern and Old Javanese', in: Světla Čmejrková and František Štícha (eds), The syntax of sentence and text; A festschrift for František Daneš, pp. 179-92. Amsterdam: Benjamins.

1995a 'Morphonology and morphology; Two systematic aspects of word structure', in: Werner Winter (ed.), On languages and language; The presidential addresses of the 1991 meeting of the Societas Linguistica Europaea, pp. 257-66. Berlin: Mouton de Gruyter.

1995b 'Georges Mounin, 20 juni 1910 - 10 januari 1993', Koninklijke Nederlandse Akademie van Wetenschappen, Levensberichten en herdenkingen (1994):81-6.

1996a 'Some remarks on homonymy and polysemy', in: Barbara H. Partee and Petr Sgall (eds), Discourse and meaning; Papers in honor of Eva Hajičová, pp. 119-26. Amsterdam: Benjamins.

1996b 'The concepts of process, category, and productivity in morphology', in: Vivien Law and Werner Hüllen (eds), Linguists and their diversions; A festschrift for R.H. Robins on his 75th birthday, pp. 395-405. Münster: Nodus.

1996c 'About cran- and cranberry', in: Bernd Nothofer (ed.), Reconstruction, classification, description; Festschrift in honor of Isidore Dyen, pp. 249-59. Hamburg: Abera. 
1996d 'De noodzaak van het vertalen' [The need for translation], in: Ton Naaijkens (ed.), Vertalers als erflaters; Staalkaart van een eeuw vertalen, pp. 181-94. Bussum: Coutinho. [With S. Dresden; reprint of 1958d.]

1997a 'In memoriam Dr. Petrus Voorhoeve, 22 december 1899 - 9 februari 1996', Bijdragen tot de Taal-, Land-en Volkenkunde 153:311-31. [With A. Teeuw.]

1997b 'Petrus Josephus Zoetmulder S.J., 29 januari 1906 - 8 juli 1995', Koninklijke Nederlandse Academie van Wetenschappen, Levensberichten en herdenkingen (1997):51-6.

2000

2000 'The word, the central unit of language', in: N.S. Babenko (ed.), Jazyk; Teorija, istorija, tipologija, pp. 28-35. Moskva: Ėditorial URSS.

2003 ‘Old Javanese word structure', in: Josef Hladký (ed.), Language and function; To the memory of Jan Firbas, pp. 307-14. Amsterdam: Benjamins.

\section{Forthcoming}

a 'Karcevski, Serge', in: Biographical dictionary of western linguistics since 1450. London: Routledge.

b 'Reichling, Anton', in: Biographical dictionary of western linguistics since 1450. London: Routledge.

\section{References}

Adelaar, Willem F.H.

2003 'E.M. Uhlenbeck, 1913-2003', International Journal of American Linguistics 69-4:397-406.

Al, B.P.F., Ariane van Santen and H. Schultink (eds)

1981 Produktiviteit in de morfologie; Een bundel artikelen opgedragen aan E.M. Uhlenbeck. Muiderberg: Coutinho. [= Forum der Letteren 22/1, special issue].

Grace, George W.

1998 'On the assumption that to learn a language is to construct a grammar', in: Mark Janse (ed.), Productivity and creativity; Studies in general and descriptive linguistics in honor of E.M. Uhlenbeck, pp. 69-81. Berlin: Mouton Janse, Mark (ed.) de Gruyter. [Trends in Linguistics, Studies and Monographs 116.]

1998a Productivity and creativity; Studies in general and descriptive linguistics in honor of E.M. Uhlenbeck. Berlin: Mouton de Gruyter. [Trends in Linguistics, Studies and Monographs 116.] 
1998b 'E.M. Uhlenbeck; A personal appreciation', in: Mark Janse (ed.), Productivity and creativity; Studies in general and descriptive linguistics in honor of E.M. Uhlenbeck, ix-xii. Berlin: Mouton de Gruyter. [Trends in Linguistics, Studies and Monographs 116.]

2003 'Eugenius Marius Uhlenbeck, 1913-2003', Oceanic Linguistics 43-1:245-57. Janse, Mark and Pierre Swiggers

1996 E.M. Uhlenbeck; Bio-bibliographical notice. Louvain: Centre Internationale de Dialectologie Générale. [Bio-bibliographies et exposés, N.S. 5.]

Kooij, Jan G. and Hein Steinhauer

2004 'E.M. Uhlenbeck, 1913-2003', Lingua 114-2:93-4.

Muysken, Pieter C.

2005 'E.M. Uhlenbeck', Koninklijke Nederlandse Academie van Wetenschappen, Levensberichten en herdeningen (2005):118-23.

Portielje, Cecile

2004 'Professor E.M. Uhlenbeck, taalkundige (1913-2003)', Voortgang 22:205-34.

Index

General and Dutch linguistics

General:

1956b, 1956c, 1957b, 1960d, 1965d, 1966a, 1967c, 1967g, 1968b, 1969b, 1970g, 1973a, 1974, 1975a, 1975d, 1976a, 1977a, 1977c, 1978b, 1978d, 1979a, 1979c, 1980a, 1980b, 1980c, 1981c, 1981d, 1981e, 1982d, 1983b, 1984b, 1990, 1991c, 1992a, 1994b, 2000

Dutch: 1958b, 1960e, 1962c, 1963e, 1964b, 1966b, 1968f, 1968g, 1968h, 1971c, 1976d, 1976e 1979b

Endangered languages: 1991a, 1991b, 1993a, 1993b

Morphology: $\quad$ 1962b, 1967i, 1977b, 1981e, 1987b, 1990, 1992b, 1995a, 1996b, $1996 \mathrm{c}$

Phonology: $\quad$ 1948, 1953d, 1954b, 1955b, 1956d, 1957a, 1959c

Semantics: $\quad$ 1964b, 1967i, 1970b, 1973a, 1973b, 1978c, 1980d, 1981a, 1981b, 1983d, 1984b, 1985b, 1992f, 1996a

Syntax: $\quad$ 1958b, 1962c, 1963a, 1964b, 1964c, 1967b, 1968g, 1971c, 1973a, 1983d, 1990,

Translation: $\quad$ 1958d, 1967f, 1996d

Javanese, Indonesian and Austronesian linguistics

Austronesian: $\quad$ 1951a, 1955d, 1958a, 1960g, 1961, 1963b, 1964a, 1965c, 1967a, $1971 d$

Indonesian: $\quad$ 1941c, 1952a

Modern Javanese: $\quad$ 1941a, 1949, 1950a, 1950b, 1953a, 1953b, 1953c, 1954a, 1955a, 1956a, 1959d, 1960b, 1963d, 1964a, 1965b, 1966c, 1969a, 1969c, 1970e, 1970h, 1971b, 1975c, 1976c, 1978a, 1983a, 1983c, 1983e, $1992 d, 1994 \mathrm{c}$

Old Javanese: $\quad$ 1952b, 1958c, 1960a, 1968c, 1970d, 1975b, 1981f, 1983f, 1985c, 1986b, 1987a, 1989a, 1991d, 1992e, 1994c, 2003 